\title{
IMPLEMENTASI MODEL LEARNING CYCLE 7E PADA PEMBELAJARAN KIMIA DENGAN MATERI POKOK KELARUTAN DAN HASIL KALI KELARUTAN UNTUK MENINGKATKAN PENGUASAAN KONSEP DAN KETERAMPILAN BERPIKIR KRITIS SISWA SMA
}

\author{
Weny Indrawati'), Suyatno ${ }^{2)}$, Yuni Sri Rahayu ${ }^{3)}$ \\ ${ }^{1)}$ Program Studi Pendidikan Sains, Program Pascasarjana Universitas Negeri Surabaya \\ ${ }^{2), 3)}$ Dosen Pascasarjana Prodi Pendidikan Sains Univesrtitas Negeri Surabaya \\ E-mail: wenyindrawati@gmail.com
}

\begin{abstract}
This research aimed to describe efectivity of 7E learning cycle model on improvement students'concept mastery and critical thinking skills. This research was conducted by three phases, namely: (1) prepation phase to develop teaching materials, (2) validation and revision phase, and (3) learning implementation phase on class using one group pretest-posttest design. The results of research showed that: (1) Realization of lesson plan with mean score of 4.68 as very good category; (2) Frequency of the dominant students'activity namely teamwork was $28 \%$ with mean reliability of $80 \%$; (3) Students' positively respond to the learning model with main score of 3.2; (4) The concepts classical mastery was $94 \%$ and the indicator mastery was 79\%; (5) The critical thinking skills classical mastery was $97 \%$, the indicator mastery was $88 \%$, and supported by high gain scores to students' concept mastery and critical thinking skills. Based on the results, it was concluded that the implementation of 7E learning cycle model on the solubility and solubility product topic was effective to improve students' the concepts mastery and critical thinking skills.
\end{abstract}

Keywords: 7E Learning Cycle Model, Solubility And Solubility Product, Concept Mastery, Critical Thinking Skills

\begin{abstract}
Abstrak: Penelitian ini bertujuan untuk mendeskripsikan efektivitas model pembelajaran learning cycle 7E terhadap peningkatan penguasaan konsep dan keterampilan berpikir kritis siswa. Penelitian ini dilaksanakan dalam tiga tahap, yaitu: (1) tahap penyusunan perangkat pembelajaran, (2) tahap validasi dan revisi, dan (3) tahap implementasi pembelajaran di kelas dengan menggunakan rancangan one group pretest-posttest design. Hasil penelitian menunjukkan bahwa: (1) Keterlaksanaan RPP dengan nilai rata-rata 4,68 dengan kategori sangat baik; (2) Frekuensi aktivitas siswa yang menonjol adalah bekerja sama dengan tim sekelompok sebesar 28\% dengan reliabilitas rata-rata 80\%; (3) Respon positif siswa terhadap model pembelajaran dengan nilai rata-rata 3,2; (4) Ketuntasan klasikal penguasaan konsep 94\% dan ketuntasan indikator 79\%; (5) Ketuntasan klasikal keterampilan berpikir kritis $97 \%$, ketuntasan indikator $88 \%$, dan didukung dengan skor peningkatan yang tinggi terhadap penguasaan konsep dan keterampilan berpikir kritis siswa. Berdasarkan hasil analisis data, diperoleh kesimpulan bahwa implementasi model pembelajaran learning cycle 7E pada materi pokok kelarutan dan hasil kali kelarutan efektif untuk meningkatkan penguasaan konsep dan keterampilan berpikir kritis siswa.
\end{abstract}

Kata kunci: Model Learning Cycle 7E, Kelarutan Dan Hasil Kali Kelarutan, Penguasaan Konsep, Keterampilan Berpikir Kritis

\section{PENDAHULUAN}

Kurikulum 2013 dikembangkan untuk menghadapi tuntutan masa depan yang membuka persaingan kehidupan semakin luas dan berdampak langsung tuntutan peningkatan sumber daya manusia. Seperti yang tercantum dalam Peraturan Menteri Pendidikan Dan Kebudayaan No. 81A Tahun 2013 tentang Implementasi Kurikulum, dijelaskan bahwa untuk memenuhi kebutuhan kompetensi masa depan maka kemampuan peserta didik yang diperlukan yaitu kemampuan berkomunikasi, berpikir kritis dan kreatif agar mampu hidup dalam masyarakat global, memiliki minat luas dalam kehidupan dan kesiapan untuk bekerja, kecerdasan sesuai dengan bakat/minatnya, dan peduli terhadap lingkungan. Kurikulum harus mampu menjawab tantangan ini sehingga perlu mengembangkan kemampuan-kemampuan ini dalam proses pembelajaran.

Proses pembelajaran kurikulum 2013 mengembangkan kreativitas, rasa ingin tahu, kemampuan merumuskan pertanyaan untuk membentuk pikiran kritis yang perlu untuk hidup cerdas dan belajar sepanjang hayat. Perubahan kurikulum menuntut guru melakukan perubahan metode dalam pembelajaran agar siswa lebih kritis, kreatif, dan inovatif dalam mempelajari sesuatu yang harus mereka ketahui, 
termasuk pembelajaran sains, khususnya kimia. Prinsip pembelajaran sains adalah mengeksplorasi fakta-fakta yang ada, melakukan eksperimen untuk menguji hipotesis, dan mengembangkan kemampuan menganalisis.

Permasalahan umum yang biasanya dialami oleh para guru selama ini, khususnya guru kimia, adalah kesulitan belajar dari siswanya dalam memecahkan permasalahan dan siswa juga tidak mampu mengkaitkan satu konsep dengan konsep lain yang telah diajarkan oleh guru. Selama ini siswa lebih sering menghafalkan konsep-konsep tersebut. Untuk meningkatkan keterampilan berpikir siswa, hendaknya pada pembelajaran kimia guru lebih melibatkan peran siswa dalam pembelajaran. Penerapan pendekatan keterampilan proses menyebabkan siswa tidak pasif menerima dan menghafal informasi yang diberikan guru, tetapi berusaha menemukan konsep melalui pengalaman langsung.

Pengalaman secara langsung dan pembiasaan sikap kerjasama dan menghargai pendapat orang lain inilah yang membawa perubahan sikap ke arah yang lebih baik serta mampu meningkatkan hasil belajar kognitif siswa (Rahayu, 2011).

Hasil pengukuran berpikir kritis siswa SMA Al Multazam dan SMA PGRI I Kota Mojokerto menggunakan beberapa indikator yaitu: (1) menjawab pertanyaan mengapa, (2) membuat kesimpulan, dan hipotesis, (3) kemampuan memberikan penjelasan, (4) mengaplikasikan prinsip yang diterima, dan (5) merumuskan alternatif yang memungkinkan untuk memecahkan masalah. Diperoleh hasil siswa yang menjawab benar dari indikator-indikator tersebut secara berturut-turut adalah 50\%, 20\%, 37\%, 27\%, dan $27 \%$. Hal ini menunjukkan bahwa keterampilan berpikir kritis siswa untuk kelima indikator tersebut masih kurang, jawaban benar semua indikator rata-rata sebesar 32,2\%.

Salah satu model berpikir kritis adalah learning cycle 7E. Menurut Mecit (2006), model learning cycle $7 E$ dapat meningkatkan keterampilan berpikir kritis siswa secara signifikan dibandingkan dengan metode tradisional, perbedaan jenis kelamin siswa dan pendapatan keluarga tidak mempengaruhi keterampilan berpikir kritis siswa dan penguasaan konsep. Model learning cycle ada beberapa macam, dalam penelitian ini digunakan learning cycle 7E. Eisenkraft (2003) menyatakan bahwa model pembelajaran learning cycle $7 E$ bertujuan untuk menekankan pentingnya memunculkan pemahaman awal siswa dan memperluas (transfer) konsep.

Dengan model baru ini, guru seharusnya tidak melewatkan tata syarat yang penting untuk proses pembelajaran. Learning cycle $7 E$ mempunyai 7 fase yaitu: (1) elicit (menetapkan pengetahuan awal siswa), (2) engage (mengajak dan menarik perhatian siswa), (3) explore (mengeksplorasi), (4) explain (menjelaskan), (5) elaborate (menerapkan), (6) evaluate (menilai), dan (7) extend (memperluas).

Pemilihan materi pada penelitian ini berdasarkan hasil angket tentang materi kimia kelas XI yang dianggap sulit oleh siswa dan hasil wawancara dengan guru kimia. Berdasarkan hasil angket, materi yang dianggap sulit adalah kelarutan dan hasil kali kelarutan sebesar 21,4\%; termokimia sebesar $14,5 \%$, dan sisanya terbagi untuk materi kelas XI lainnya. Oleh karena itu, materi yang dipilih dalam penelitian ini adalah kelarutan dan hasil kali kelarutan.

Hasil wawancara guru mengenai kesulitan yang biasa dihadapi siswa pada materi kelarutan dan hasil kali kelarutan adalah kekurangtepatan mengionisassi zat elektrolit, sehingga apabila siswa salah mengionisasi maka penulisan persamaan $\mathrm{K}_{\mathrm{sp}}$ dan perhitungan harga $\mathrm{K}_{\mathrm{sp}}$ nya juga salah, walaupun sebenarnya cara pengionisasian telah diberikan di kelas $\mathrm{X}$ pada materi tata nama senyawa. Kesulitan berikutnya adalah pengaruh ion senama terhadap kelarutan, siswa sulit untuk menentukan kelarutan suatu zat akibat penambahan ion senama dari tetapan hasil kali kelarutan yang diketahui.

Materi pokok kelarutan dan hasil kali kelarutan merupakan salah satu materi pada kelas XI semester dua. Siswa dapat memahami konsep kelarutan dan hasil kali kelarutan dengan baik apabila pada siswa telah paham tentang konsep-konsep yang telah dipelajari sebelumnya dan berhubungan dengan materi tersebut, seperti konsep mol, persamaan reaksi, dan konsentrasi zat elektrolit.

Berdasarkan hasil analisis sesuai dengan karakteristik materi dan kondisi siswa, maka diusulkan untuk mengimplementasikan model learning cycle $7 E$ pada materi pokok kelarutan dan hasil kali kelarutan. Marek (2008) menyatakan bahwa learning cycle merupakan cara inkuiri pada pelajaran sains yang terdiri dari beberapa tahap yang berurutan. Learning cycle mengubah pola pikir siswa melalui investigasi sains dengan mengeksplorasi materi, membangun konsep, dan mengaplikasikan atau mengembangkan konsep pada kondisi lain.

Berdasarkan uraian di atas maka penulis bermaksud melakukan penelitian yang berjudul "Implementasi Model Learning Cycle 7E pada Pembelajaran Kimia dengan Materi Pokok Kelarutan dan Hasil Kali Kelarutan untuk Meningkatkan Penguasaan Konsep dan Keterampilan Berpikir Kritis Siswa SMA".

\section{METODE PENELITIAN}

Penelitian yang dilakukan adalah penelitian praeksperimental yang didahului dengan penyusunan perangkat pembelajaran. Uji coba implementasi model 
learning cycle $7 E$ pada materi pokok kelarutan dan hasil kali kelarutan menggunakan desain penelitian praexperimental dengan bentuk one-group pretest-postest design. Penelitian digunakan untuk mengetahui pengaruh implementasi model learning cycle $7 E$ terhadap penguasaan konsep dan keterampilan berpikir kritis. Perangkat pembelajaran yang disusun berupa Rencana Pelaksanaan Pembelajaran (RPP), Lembar Kegiatan Siswa (LKS), Handout, Tes Penguasaan Konsep, Tes Keterampilan Kritis pada pembelajaran kimia materi kelarutan dan hasil kali kelarutan dengan model pembelajaran berbasis learning cycle $7 E$. Perangkat pembelajaran tersebut selanjutnya divalidasi oleh pakar dan praktisi pendidikan sebelum diimplemetasikan di kelas.

Subyek dalam penelitian ini adalah penguasaan konsep dan keterampilan berpikir kritis siswa kelas XI SMA PGRI I Kota Mojokerto setelah implementasi model pembelajaran learning cycle $7 E$ pada materi pokok kelarutan dan hasil kali kelarutan. Jumlah siswa yang terlibat dalam pembelajaran sebanyak 12 siswa.

Instrumen yang digunakan dalam pengumpulan data terdiri dari lembar validasi perangkat pembelajaran, lembar penilaian keterbacaan handout dan LKS, lembar penilaian keterlaksanaan RPP, lembar pengamatan aktivitas siswa, angket respon siswa, lembar penilaian penguasaan konsep, dan lembar penilaian keterampilan berpikir kritis.

Data hasil validasi perangkat pembelajaran, pengamatan keterlaksanaan RPP, aktivitas siswa, respon siswa, penguasaan konsep, dan keterampilan berpikir kritis dianalisis secara deskriptif. Peningkatan penguasaan konsep dan keterampilan berpikir kritis dianalisis dengan analysis of gain scores (Hake, 2009).

\section{HASIL PENELITIAN DAN DISKUSI}

\section{A. Validitas Perangkat Pembelajaran}

Validasi perangkat pembelajaran meliputi RPP, handout, LKS, Tes Penguasaan Konsep, dan Tes Keterampilan Berpikir Kritis, dilakukan validasi oleh pakar dan praktisi pendidikan sebelum diimplentasikan dalam pembelajaran.

Dari hasil validasi RPP, handout, LKS, Tes Penguasaan Konsep, dan Tes Keterampilan Berpikir Kritis diperoleh skor rata-rata masing-masing 4,68 dengan kategori valid; 4,46 dengan kategori valid; 4,71 dengan kategori valid; 4,70 dengan kategori valid, 4,78 dengan kategori valid. Dengan demikian perangkat pembelajaran yang dikembangkan layak digunakan dalam pembelajaran.

Hasil penilaian keterbacaan handout dan LKS materi pokok kelarutan dan hasil kali kelarutan dianalisis dan digambarkan masing-masing seperti Gambar 1 dan Gambar 2.

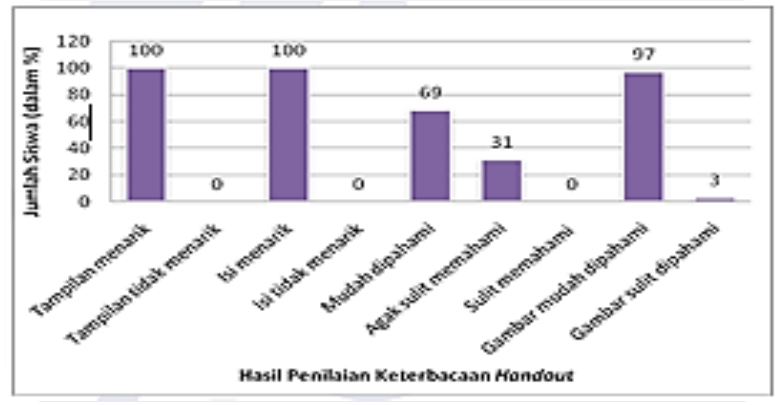

Gambar 1. Keterbacaan Siswa terhadap Handout

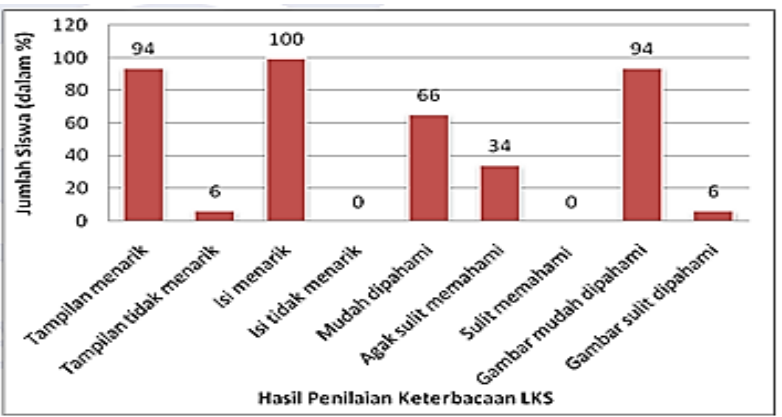

Gambar 2. Keterbacaan Siswa terhadap LKS

\section{B. Keterlaksanaan RPP}

Pengamatan terhadap keterlaksanaan RPP dalam pembelajaran model learning cycle $7 E$ pada materi pokok kelarutan dan hasil kali kelarutan dilakukan oleh dua pengamat. Pengamatan dilakukan pada tiga kali pertemuan, pertemuan I tentang reaksi pengendapan, pertemuan II mempelajari tentang pengaruh ion senama dan $\mathrm{pH}$ terhadap kelarutan, dan pertemuan III mengenai kelarutan dan hubungannya dengan hasil kali kelarutan. Skor rata-rata pengamat untuk ketiga pertemuan sebesar 4,68 dan reliabilitas instrumen sebesar $86,7 \%$. Secara umum keterlaksanaan RPP termasuk kategori sangat baik dan reliabel.

\section{Aktivitas Siswa}

Berdasarkan hasil analisis data, persentase seluruh aspek aktivitas siswa yang diamati oleh dua orang pengamat diperoleh reliabilitas sebesar $80,3 \%$, hal ini menunjukkan bahwa pengamatan tersebut reliabel (ajeg). Data selanjutnya disajikan dalam bentuk diagram seperti pada Gambar 3.

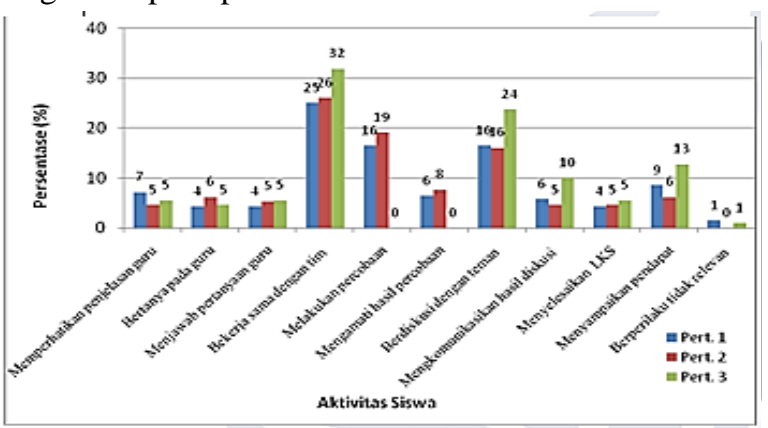

Gambar 3. Aktivitas Siswa dalam Pembelajaran dengan Model Learning Cycle $7 E$ 
Aktivitas siswa yang diamati merupakan serangkaian kegiatan siswa selama proses pembelajaran berlangsung. Hasil analisis aktivitas siswa menunjukkan bahwa aktivitas yang dominan pada pertemuan 1,2 , dan 3 adalah bekerja sama dengan tim kelompok, dengan frekuensi rata-rata sebesar $28 \%$. Aktivitas ini berperan dalam peningkatan penguasaan konsep dan keterampian berpikir kritis siswa, karena tutor teman sebaya dalam kelompok akan melibatkan siswa dalam pembelajaran yang aktif, seorang siswa mengajar siswa yang lain, dan memungkinkan guru untuk membimbing serta memantau pembelajaran di kelas, tutorial teman sebaya serring memberikan manfaat pada prestasi siswa (Santrock, 2009).

Frekuensi lebih rendah berikutnya adalah berdiskusi dengan teman sekelompok, sebesar 19\%. Hal ini dikarenakan siswa pada fase explore hingga elaborate sudah membentuk kelompok untuk berdiskusi, melakukan dan mengamati percobaan, mengkomunikasikan hasil percobaan, dan menerapkan konsep, sehingga frekuensi aktivitas siswa lebih dominan dari yang lainnya. Pembentukan kelompok dilakukan agar siswa dapat bekerja sama dengan siapapun. Hal tersebut sesuai dengan prinsip teori pembelajaran konstruktivisme bahwa proses mengkonstruksi pengetahuan melibatkan aspek sosial (Soeprodjo, dkk., 2008).

\section{Respon Siswa}

Responden (siswa) diminta untuk membaca pernyataan yang disajikan dan memberi respon dengan cara memilih salah satu kategori yang sesuai dengan menggunakan skala Likert. Hasil analisis disaijikan dalam bentuk diagram pada Gambar 4 .

Hasil menunjukkan bahwa sebanyak 63\% siswa lebih termotivasi dalam proses pembelajaran dengan model learning cycle $7 E$, hal ini sesuai dengan hasil analisis keterlaksaaan RPP, karena siswa termotivasi dengan baik dalam proses pembelajaran maka RPP juga dapat terlaksana dengan baik, sehingga skor rata-rata keterlaksanaan RPP sebesar 4,68 dengan kategori sangat baik; $81 \%$ siswa setuju bahwa model pembelajaran learning cycle $7 E$ membuat siswa lebih aktif, karena model pembelajaran tersebut berpusat pada siswa sehingga menjadikan siswa lebih aktif daripada pembelajaran yang berpusat pada guru. Menurut Bruner, cara-cara pembelajaran pada guru dapat merangsang motivasi belajar siswa, yaitu pengalaman dimana para siswa berpartisipasi aktif dalam menghadapi alamnya (Dahar, 2006). Sebanyak 88\% siswa setuju bahwa mereka lebih bisa mengemukakan pendapat dalam diskusi; $59 \%$ siswa sangat setuju bahwa pembelajaran dengan model learning cycle $7 E$ lebih menyenangkan apabila disertai eksperimen, hal tersebut dapat membuat siswa lebih aktif dan termotivasi untuk mempelajari materi kelarutan dan hasil kali kelarutan karena dapat mengaplikasikan teori secara langsung dan tidak membosankan; pembelajaran disertai dengan eksperimen juga dapat lebih memudahkan siswa untuk memahami materi tersebut, hal ini ditunjukkan dengan respon semua siswa yang menyatakan setuju; 69\% siswa lebih bisa bekerja sama dengan model pembelajaran learning cycle $7 E$, karena siswa dibagi menjadi beberapa kelompok untuk berdiskusi dan eksperimen sehingga kesempatan untuk bekerja sama sangat besar; $66 \%$ siswa setuju bahwa soal-soal lebih mudah diselesaikan dalam model pembelajaran learning cycle $7 E$, karena model pembelajaran tersebut terdiri dari beberapa tingkatan fase yang dapat mengkonstruksi konsep siswa sesuai teori Piaget, dalam kelompok siswa dapat saling bertukar berpendapat tentang konsep yang mereka pahami, dengan adanya proses scaffolding maka siswa mampu menyelesaikan permasalahan yang ada sehingga dapat meningkatkan penguasaan konsepnya (Ibrahim, 2008); begitu pula dengan keterampilan berpikir kritis, hal ini ditunjukkan dengan respon siswa sebesar $66 \%$.

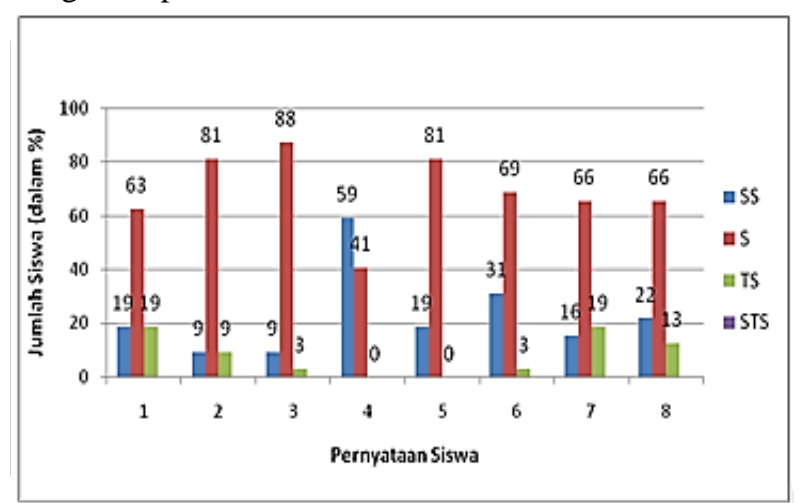

Gambar 4. Respon Siswa terhadap Pembelajaran dengan Model Learning Cycle $7 E$

Dari semua aspek pada angket respon siswa, diperoleh nilai rata-rata sebesar 3,2 dengan kategori setuju. Dapat disimpulkan bahwa siswa memberikan respon yang baik terhadap pembelajaran dengan model learning cycle $7 E$. Respon yang baik terhadap pelajaran tertentu akan meningkatkan minat dan mendorong tindakan positif siswa untuk menekuni dan meningkatkan intensitas belajar pada pelajaran tersebut (Ratumanan, 2006: 93).

\section{E. Penguasaan Konsep Siswa}

Tes penguasaan konsep terdiri dari pretest dan posttest dengan soal yang sama pada materi kelarutan dan hasil kali kelarutan sebanyak 10 butir soal pilihan ganda. Dalam proses pembelajaran, siswa menggunakan handout dan LKS dengan model learning cycle $7 E$. Dari sebanyak 12 siswa yang mengikuti pembelajaran dengan model learning cycle $7 E$, 
diperoleh hasil posttest yang meningkat dengan skor peningkatan mulai kategori sedang $(0,5)$ sampai tinggi $(1,0)$, seperti yang pada Gambar 5 .

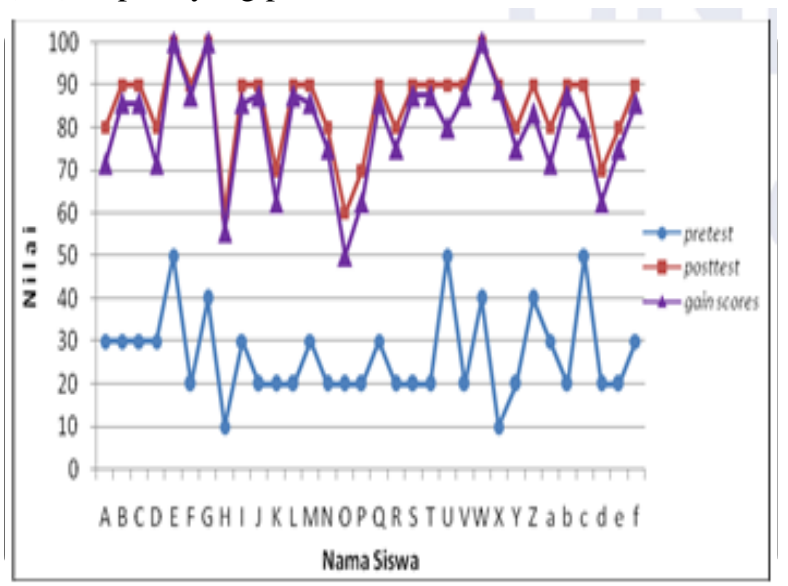

Gambar 5. Hasil Penilaian Penguasaan Konsep dan Peningkatannya

Hal ini sesuai dengan penelitian yang dilakukan oleh Indriyani (2013) untuk pembelajaran fisika dengan materi yang sejenis dengan materi kelarutan dan hasil kali kelarutan, yaitu materi elektromagnetik. Penelitian tersebut menyatakan bahwa terjadi peningkatan yang signifikan terhadap hasil belajar pembelajaran yang menggunakan pembelajaran LKS berbasis learning cycle $7 E$. Penyusunan LKS dimulai dari fase elicit untuk mendatangkan pengetahuan awal dengan mengajukan pertanyaan yang dari kegiatan dalam kehidupan sehari-hari sehingga menambah rasa ingin tahu siswa terkait materi kelarutan dan hasil kali kelarutan. Hal ini sesuai dengan teori belajar Piaget yang menyatakan bahwa pada proses asimilasi individu menggunakan struktur kognitif yang sudah ada untuk memberikan respon terhadap rangsangan yang diterimanya. Perolehan konsep baru akan berdampak pada konsep yang telah dimiliki individu. Individu harus dapat menghubungkan konsep yang baru dipelajari dengan konsep-konsep lain dalam suatu hubungan antar konsep (Dahar, 2006).

\section{F. Keterampilan Berpikir Kritis}

Analisis hasil tes keterampilan berpikir kritis menunjukkan bahwa keterampilan berpikir kritis siswa mengalami peningkatan. Dari hasil pretest diketahui bahwa tidak siswa yang tuntas baik secara individu maupun klasikal, setelah proses pembelajaran dengan model learning cycle $7 E$ terdapat peningkatan yang sangat signifikan yaitu siswa tuntas $97 \%$ secara individu dan klasikal. Hal ini sesuai dengan penelitian yang dilakukan oleh Hartono (2013), bahwa keterampilan berpikir kritis siswa meningkat setelah pembelajaran learning cycle, model learning cycle $7 E$ dikembangkan untuk membantu siswa meningkatkan berpikir mereka, menyelesaikan masalah, dan kemampuan intelektualnya. Model learning cycle $7 E$ diaplikasikan tidak hanya untuk meningkatkan ketrampilan berpikir kritis siswa namun juga untuk meningkatkan hasil belajar siswa.

Siswa mendapat skor peningkatan terendah 0,34 dengan kategori sedang, siswa yang lain lebih dari 0,95 dengan kategori tinggi, seperti pada Gambar 6. Hal ini menunjukkan bahwa model pembelajaran learning cycle $7 E$ mampu meningkatkan keterampilan berpikir kritis siswa. Learning cycle $7 E$ merupakan model yang memberikan kebebasan pada siswa untuk menyatakan ide-ide mereka, mempertimbangkan pendapat alternatif dan berdiskusi, serta bekerja sama dengan teman. Hal ini merupakan strategi yang baik guru untuk mengembangkan kemampuan berpikir kritis (Mecit, 2006).

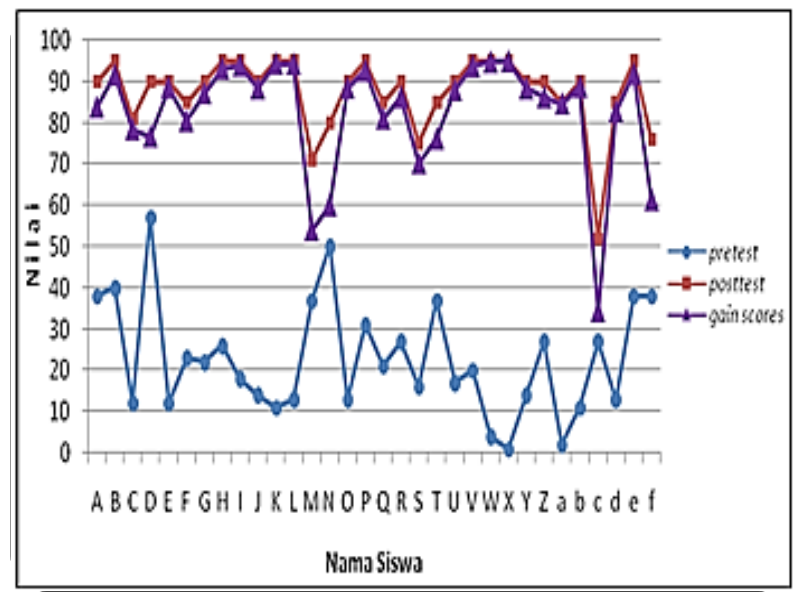

Gambar 6. Hasil Penilaian Keterampilan Berpikir Kritis dan Peningkatannya

Data skor peningkatan juga didukung oleh hasil analisis sensivitas butir soal yang menunjukkan indeks sensivitas terendah 0,3 ; hal ini menunjukkan bahwa soal keterampilan berpikir kritis yang digunakan memiliki kepekaan yang cukup terhadap efek-efek pembelajaran.

Indikator tes keterampilan berpikir kritis siswa meliputi: (a) menjawab pertanyaan mengapa; (b) kemampuan memberikan penjelasan; (c) membuat kesimpulan, dan hipotesis; (d) mengaplikasikan prinsip yang diterima; dan (e) merumuskan alternatif yang memungkinkan untuk memecahkan masalah. Persentase ketuntasan indikator pretest rata-rata sebesar 6\% dan termasuk kategori tidak tuntas. Pada hasil posttest terjadi peningkatan skor tes, sehingga terjadi peningkatan pula pada ketuntasan indikatornya. Ketuntasan indikator secara keseluruhan tuntas dengan persentase sebesar $88 \%$. Kemampuan berpikir kritis seorang siswa akan sangat membantu mengambil keputusan secara tepat, cermat, sistematis, benar dan logis, dengan mempertimbangkan berbagai sudut pandang atau aspek (Dwijananti, 2010). Keputusan inilah yang dijadikan sebagai solusi dari suatu permasalahan. 


\section{KESIMPULAN}

Berdasarkan hasil analisis data dan pembahasan yang telah dilakukan, maka dapat diperoleh kesimpulan yaitu implementasi pembelajaran dengan model learning cycle $7 E$ pada materi pokok kelarutan dan hasil kali kelarutan efektif untuk meningkatkan penguasaan konsep dan keterampilan berpikir kritis siswa.

\section{REFERENSI}

Aiken, L. R. (1997). Psychological Testing and Assesment. New York: Allyn and Bacon.

Amri, S. (2013). Pengembangan dan Model Pembelajaran dalam Kurikulum 2013. Jakarta: PT. Prestasi Pustakakarya.

Arikunto, S. (2010). Prosedur Penelitian: Suatu Pendekatan Praktik (Edisi Revisi). Yogyakarta: Rineka Cipta.

Arikunto, S. (2012). Dasar-Dasar Evaluasi Pendidikan. Jakarta: Bumi Aksara.

Australian Council for Educational Research (ACER). (2011). Highlights from TIMSS and PIRLS 2011: The Australia's Perspective. Diakses melalui www.acer.edu.au/documents/TIMSSPIRLS-Australian-Highlights.pdf : tanggal 4 Mei 2014.

Borich, G. D. (1994). Observation Skills for Effective Teaching. New York: MacMillan Publishing Company.

Cahyono, A. N. (2006). Vygotskian Perspective: Proses Scaffolding untuk Mencapai Zona of Proximal Development (ZPD) Peserta Didik dalam Pembelajaran Matematika. Makalah Seminar Nasional Matematika dan Pendidikan Matematika, FMIPA UNY. Diakses melalui http://eprints.uny.ac.id/: tanggal 7 Juli 2014.

Chang, R. and Overby, J.(2011). General Chemistry: The Essential Concepts. New York: McGrawHill Companies Inc.

Dahar, R.W. (1988). Teori-Teori Belajar. Bandung: Erlangga.

Dahar, R.W. (2006). Teori-Teori Belajar dan Pembelajaran. Bandung: Erlangga.

Dwijananti, P. dan Yulianti, D. (2010). Pengembangan Kemampuan Berpikir Kritis Mahasiswa melalui Pembelajaran Problem Based Instruction pada Mata Kuliah Fisika Lingkungan. Jurnal Pendidikan Fisika Indonesia, Vol. 6, pp. 108-114.

Eisenkraft. (2003). Expanding the 5E Model. The Science Teacher. Vol. 70, No. 6, pp. 56-59.

Ennis, R. H. (1985). "A Logical Basis For Measuring Critical Thinking Skills." Education Leadership, Vol. 43, No. 2, pp. 44-48.

Ennis, R. H. (1996). Critical Thinking. New York: Prentice-Hall Inc.
Fisher, A. (2007). Berpikir Kritis: Sebuah Pengantar. Jakarta: Erlangga.

Gronlund, N. E. (1981). Measurement and Evaluation Teaching. Canada: Collier Macmillan Canada, Ltd.

Hake, R. R. (1999). Analyzing Change/Gain Scores. Woodland Hills. Diakses melalui http://physics.indiana.edu/sdi/analyzingchange _gain.pdf: tanggal 2 Mei 2014.

Hartono. (2013). Learning Cycle 7E Model to Increase Student's Critical Thinking on Science. Jurnal Pendidikan Fisika Indonesia, Vol. 9, pp. 5866.

Ibrahim, M. (2008). Model Pembelajaran Inovatif IPA melalui Pemaknaan. Surabaya: Departemen Pendidikan Nasional. Balitbang Puslitjaknov.

Ibrahim, M., dkk. (2010). Dasar-dasar Proses Belajar Mengajar. Surabaya: Unesa University Press.

Ibrahim, M. (2012). Konsep, Miskonsepsi, dan Cara Pembelajarannya. Surabaya: Unesa University Press.

Indriyani, I. R. (2013). Pengembangan LKS Fisika Berbasis Siklus Belajar (Learning Cycle) $7 E$ untuk Meningkatkan Hasil Belajar dan Mengembangkan Kemampuan Berpikir Kritis pada Siswa SMA Kelas X Pokok Bahasan Elektromagnetik. Tesis Magister Pendidikan Fisika, Universitas Ahmad Dahlan.

Jespersen, N.D. and Brady, J.E. (2012). Chemistry: The Molecular Nature of Matter. New York: John Wiley and Sons Inc.

Marek, E.A. (2008). "Why Learning Cycle?”. Journal of Elementary Science Education, Vol 20, No. 3, pp. 63-99.

Mecit, O. (2006). The Effect of $7 E$ Learning Cycle Model on The Improvement of Fifth Grade Students' Critical Thinking Skills". Doctoral Dissertation, Middle East Technical University.

Mendikbud. (2013). Implementasi Kurikulum. Jakarta: Kepala Biro Hukum dan Organisasi Kemendikbud.

Mendikbud. (2013). Standar Isi untuk Pendidikan Dasar dan Menengah. Jakarta: Kepala Biro Hukum dan Organisasi Kemendikbud.

Mendikbud. (2013). Standar Kompetensi Kelulusan untuk Pendidikan Dasar dan Menengah. Jakarta: Kepala Biro Hukum dan Organisasi Kemendikbud.

Nuhoglu, H. and Yalcin, N. (2006). The Effectiveness of The Learning Cycle Model to Increase Students' Achievement In The Physics Laboratory. Journal of Turkish Science Education, Vol 3, No. 2, pp. 28-30.

Nur, M. (2004). Teori-Teori Perkembangan Kognitif. 
Surabaya: Penerbit Unesa University Press.

Nur, M. (2011). Model Pembelajaran Langsung. Surabaya: Penerbit Unesa University Press.

Organisation for Economic Co-operation and Development (OECD). (2013). "Pisa 2012 results: which country does best at reading, maths and science?". Diakses melalui http://www.theguardian.com/news/datablog/20 13/dec/03/ pisa-results-country-best-readingmaths-science : tanggal 9 april 2014.

Petrucci, R. dan Suminar. (Eds). (1987). Kimia Dasar: Prinsip \& Terapan Modern. Bogor: Erlangga.

Phillips, J.S., Strozak, V. and Wistrom, C. (2002). Chemistry: Concepts and Applications. Ohio: Glencoe/McGraw-Hill Companies Inc.

Rahayu, E., Susanto, H. dan Yulianti, D. (2011). "Pembelajaran Sains dengan Pendekatan Keterampilan Proses untuk Meningkatkan Hasil Belajar dan Kemampuan Berpikir Kreatif Siswa”. Jurnal Pendidikan Fisika Indonesia, hlm 106-110. Diakses melalui http://journal.unnes.ac.id: tanggal 8 Desember 2013.

Ratumanan, T. G. dan Laurens, T. (2003). Evaluasi Hasil Belajar yang Relevan dengan Kurikulum Berbasis Kompetensi. Surabaya: Unesa University Press.

Santrock, J. W. (2009). Psikologi Pendidikan: Educational Psychology. Jakarta: Salemba Humanika.

Soeprodjo, Priatmoko, S. dan Sariana, E. Y. (2008). Pengaruh Model Learning Cycle terhadap Hasil Belajar Materi Kelarutan dan Hasil Kali Kelarutan. Jurnal Inovasi Pendidikan Kimia, Vol. 2, No. 1, pp. 224-229.

Sridana, N. 2007. Pengembangan Model Pelatihan untuk Penyusunan Rincian Materi Pengalaman Belajar Matematika bagi Guru Kelas VII melalui Penerapan Kriteria Pemilihan yang Berbasis Konstruktivisme. (Disertasi Pendidikan Matematika tidak dipublikasikan), Universitas Negeri Surabaya.

Sugiyono. (2010). Metode Penelitian Kuantitatif, Kualitatif, dan $R \& D$. Bandung: Alfabeta.

Sudjana, N. (2012). Penilaian Hasil Proses Belajar Mengajar. Bandung: PT. Remaja Rosdakarya.

Thiagarajan, S., Semmel, D.S. and Semmel M.I. (1974). Instructional Development for Training Teachers of Exceptional Children: A Sourcebook. Bloomington: Indiana University.

Verawati, E. (2013). Pengembangan Perangkat Pembelajaran Berbasis Model Learning Cycle $5 E$ untuk Meningkatkan Penguasaan Konsep dan Keterampilan Berpikir Kritis Siswa SMK pada Materi Pokok Laju Reaksi. (Tedak tipublikasikanMagister Pendidikan Sains tisa), Universitas Negeri Surabaya.

Watkins, M. W. and Pacheco, M. (2001). "Interobsever Agreement in Behavioral Research: Importance and Calculation". Journal of Behavioral Education, Vol. 10, No. 4, pp. 205212.

Widhy, P. 2012. Learning Cycle Sebagai Upaya Menciptakan Pembelajaran Sains yang Bermakna. Prosiding Seminar Nasional Penelitian, Pendidikan dan Penerapan MIPA UNY.

Woolfolk, A. (2009). Educational Psychology: Active Learning Edition. Yogyakarta: Pustaka Pelajar.

Yamin, M. (2013). Strategi dan Metode dalam Model Pembelajaran. Jakarta: GP Press Group. 